\title{
Globalization of education: the experience of retrospective complex analysis
}

\author{
Olga N. Machekhina ${ }^{1, *}$ \\ ${ }^{1}$ MIOE, Department of Interactive technologies in education, 105062, Moscow, Russia
}

\begin{abstract}
The author has presented the complex analysis of processes of globalization of education, the most active proceeding in the modern world on wide theoretical material in the article. It is noted by results of research, that it is possible to allocate two general directions within which education is globalizing directly - transformation of structure of education under the influence of objective factors of the globalizing world and formation of competences as platform of innovative educational universals on which new global education will be constructed according to their adherents.
\end{abstract}

Considering the development of education and training at the present day, in the age of globalization, it should be noted that, according to the modern trends, future development of this sector is associated with two key concepts, such as globalization and competencies. In fact, these concepts become the benchmarks, from the point of view of which the future of specific national and, indeed, the continental educational system as a whole is determined. But, at the same time, they also become the templates over which people try to predict and plan the future. Under these conditions, the clarity of presentation about the future development of national education is able to provide a clear understanding of globalization and of how and in what way it, as a phenomenon and a process, affects education.

However, it should be noted that the genesis of educational globalization began even before the actual process of globalization has begun frontally in the world. Its initial phase, of course, was the internationalization of education, which took place in the last quarter of the XIX century, and almost in the entire XX century. Therefore, in the author's opinion, it may be qualified as a platform of contemporary globalization of education and training.

International educational activities long before the end of the XX or beginning of the XXI centuries were used as a tool to improve the quality and level of training of personnel through exchange of experience, optimization of the scope of knowledge and experience proper to a national education system [1]. Modern impetus of educational globalization can be qualified as an evolution of this tradition. Higher education, in particular, has been and continues to be an effective arena for international exchange and cooperation programs. Their intensity at the end of the last century allowed some scientists argue that universities are inherently subjects of international relations. One of the first who expressed such idea was Clark Kerr, chancellor, and later, president of California University, USA, which, in particular, noted that universities, promoting knowledge all over the world are, in this sense, fully-fledged players of international relations [2]. This view has gained many supporters, one of the most striking and consistent among them is Hans de Wit. At the same time, such ideas have also spread in the domestic education theory [3].

During the XX century, many quite large international educational processes have been used primarily as diplomatic and political means. In the context of the confrontation between the superpowers of the time, the USSR and the US, education has become an important strategic tool. Both had clear political reasons to promote international education exchanges and cooperation, in order to get a clearer idea about the rest of the world and to support and, in some cases, to expand its sphere of influence.

Considering the globalization of the world as a whole and, of course, international education, it should be noted that prevailing methodological trend today is the one, in which a common understanding of globalization, a priori, determines the definitions of specific processes that are included in this mega-process. Accordingly, the understanding of the globalization of education derives from the definition that is given to globalization as such. Attempts to define the educational globalization from such positions were repeatedly made at the end of last and the beginning of this century. For example, $\mathrm{T}$. Friedman in 1999 gave the simplest, but also the most politicized definition of globalization as an international system, which replaced the system of the Cold War, from which, in his work "The Lexus and the Olive Tree", he concluded, that educational globalization [globalized education] is an education, which replaced the global education system that existed in conditions of the Cold War [4].

\footnotetext{
Corresponding author: helga mon@mail.ru
} 
A little later, the key approaches were identified to the understanding of globalization in general and, as a consequence, to the definition of the educational globalization. One of the first who tried to develop such a definition was Leon Tikly, professor of the University of Bristol. In his work «Globalization and Education in the post-colonial world» (2001) he noted, in particular, that globalization, in his opinion, is, first of all, the spread of religions and cultures, which takes place today in the vast scale and very rapidly, for which as the basis serves the availability of information about other cultures and religions deriving from education, which enables us to interpret his understanding of the place of education in the context of globalization, as its key tool [5].

In as little as three years, in 2004, a well-known sociologist Charles Tilly proposed his own understanding of globalization in general and, as a result, the understanding of the education globalization. In his opinion, expressed in his work "Past, Present, and Future Globalizations", the essence of this process is an extension from regional to transcontinental scale of social relations, methods and practices. On this basis, he proposes to adopt the spread of educational methods, practices and models from regional (national) to transcontinental scale for the understanding of the educational globalization [6].

In turn, in 2006, A. Pennycook suggested to understand the globalization of education, first of all, and globalization in general, as an era of unprecedented spread of English language as a global, which is characterized by the emergence of new hybrid forms of the language, due to the mass movement and interaction of people around the world and a threat towards dying national languages, stemming from the forces of linguistic homogenization, as the key characteristics of globalization [7].

In the same 2006, team of authors M. and C. SuarezOrozco proposed a comprehensive understanding of globalization which is applicable, in their view, to the definition of educational globalization, consisting of many components, namely:

Component 1 - post-nationalization of production, distribution and consumption of goods and services - the evolution of the levels of international trade, foreign direct investment flows and single capital market;

Component 2 - appearance of new information, communications and media technologies, which, in fact, form a knowledge-based economy;

Component 3 - international migration of unprecedented level, bearing significant demographic and cultural changes in most countries and regions of the world [8].

In these circumstances, Eugene Murphy, assessing the impact of globalization on education, describes it as a multi-layer, large-scale and having a high degree of transforming activity [9]. Such an approach allows him and a number of researchers, such as, for example, $\mathrm{T}$. Monahan, to express doubts about the possibility to concretely define the essence of education globalization and criteria of undergoing changes [10]. That is why, in their opinion, today there is an abundance of concepts and works in the area of understanding the formation of globalization and attempts to predict it.

However, by the beginning of this decade, two main trends have distinguished in understanding the practice of globalization processes in education that are not reducible to each other. Firstly, it is the trend of understanding education globalization as a transformation of the structure and an organization of education systems (and, broader, as an education space), under the influence of objective processes of globalization. Second, is the transition of education formally, structurally and substantively on the platform, consisting of a specific set of universals, today called skills [11]. We will consider these tendencies in more detail.

When considering the first direction, it should be noted that, in its essence, according to the adherents, is the transformation of the cognitive field of education, with three major components in the foreground:

a) personal abilities, basic knowledge and empirical skills, such as educability and numeracy, basic scientific knowledge and technological skills;

b) cognitive and metacognitive skills of a higher order, such as critical thinking and creative problem solving;

c) at the highest level, the ability to establish relations and interrelations between the elements of the various branches, to identify relationships between them, to evaluate prospects turns on [12].

Within this understanding of the education globalization, its content and set of objects remains practically unchanged, and the system is global only in full and not in a truncated form. For example, the first component includes traditional disciplinary subjects such as native language, mathematics, history and science. Although these objects, as such, cannot be global in nature, they exist within the framework of this component and are implemented to the necessary extent, as building blocks of the educational foundation that provide further knowledge acquisition, formation and development of skills. At the same time, they also serve as a platform to explore emerging global interdependence, cultural diversity and international issues.

Considering the second trend, it should be noted that in recent years there were many attempts to define global skills. In the author's opinion, the most successful of them were presented by F. Reimers, who believes that "Global competency [is] the knowledge and skills that help people understand the flat world in which they live and the skills to integrate across disciplinary domains to comprehend global affairs and events and to create possibilities to address them. Global competencies are also the attitudinal and ethical dispositions that make it possible to interact peacefully, respectfully and productively with fellow human beings from diverse geographies" [13].

This definition, showing the essence of global competencies, most clearly reveals the duality of their interpretation, where they are characterized not only by the knowledge, skills and abilities in any field or discipline, but also by worldview and moral attitudes, 
from the standpoint of which they are implemented externally. Therefore, education, globalized within a second trend, is understood in the double unity of the educational process and the process of moral development of students, where the latter's not only absorb information and learn one or another action, but also acquire a system of positive social values, based on which they act in the family, in social and professional group, in the community, build relationships with people of different nationality, race, etc.

However, the scenarios of educational globalization discussed above are not the only ones. So, the team of Russian authors composed of academician of Russian Academy of Education V.A. Myasnikov, I.A. Tagunova, N. N. Naidenova, in their multi-authored monograph «Education in the global dimension» see several aspects in the globalization of education, namely:

1. The convergence of the poles in question of the organization of education, expressed in the attraction of countries with strong centralization (France, Italy, Spain, Portugal, Iceland, Greece, Russia) to decentralization, and countries with decentralized system of education (United Kingdom, Denmark, USA) to centralization through the strengthening of federal control unit of education system, introduction of standard state curricula and study programs.

2. Change of the general educational paradigm, which is expressed in the approximation of a collectivist approach to education (Greece, France, Portugal, Spain, USA, Japan, Russia) with rigidly individualized (United Kingdom, partially Germany) in the form of co-operative one, which implies the integration of group and individual needs, opportunities, goals and objectives for the overall result of joint activities.

3. The convergence of different approaches in education: encyclopedic (France, Russia, Spain, Portugal, Belgium, Italy), naturalistic (Germany, United Kingdom, Denmark), pragmatic (USA) and humanitarian (UK). There is also convergence of reproductive (Japan, Russia) and problem (USA, UK) approaches. The effective is considered their rational combination, the use of each one to help and support the other. The preference to the development of students' individual abilities disappears: either critical (Japan, Russia) or creative (UK, USA). The expediency of equivalent formation of both qualities becomes obvious. The need for an interdisciplinary approach is emphasized [14].

Corresponding Member of Russian Academy of Education B.L. Wulfson differently assesses the prospects of the educational globalization. Giving the globalization of education the essential evaluation, in his work «Western European education space of the XXI century: prediction models» considers and justified five possible scenarios of its transformation:

1. Training education - the main task to bring the largest possible number of students to a lasting mastery of basic knowledge. Socialization of students, development of their emotional sphere are assigned to different social institutions which will develop a close partnership with education.

2. The selective education - the top priority is given to students' ability to absorb the most complex material as quickly as possible, others are eliminated.

3. Education as a sociocultural environment, where it is supposed to establish the optimal dialectical balance between training and education in the broadest sense of the word. It should ensure the individual development of each student and to form conscious and responsible citizens of the future society.

4. Technological education aimed at the general and widespread use of not only modern, but also future technical means of education. The whole learning process will change radically, and will take place on home TV screens and in the training centers with huge data banks, rather than at school.

5. Differentiated education, providing education on individual curricula [15].

At the same time, A.K. Savina, on the basis of the analysis of trends in the development of Western European education, points out in her work «The Development of the European education system in the Third Millennium» following perspectives of globalization:

- development of qualifications and skills needed for the society of knowledge, accessibility of information and communication technologies, increasing the student recruitment in the areas of technical and natural science, increase in spending on education;

- increasing access to education through the creation of open educational space, renovation and improvement of the education process, ensuring equality of educational opportunities;

- integration of education systems with the outside world as an essential factor in strengthening ties with the world of work, research institutions, employers and employees, the development of entrepreneurship, promoting foreign language learning, increasing mobility and exchange of pupils, students and teachers, strengthening European cooperation [16].

Today, education experiences the most powerful effect of different drivers of globalization, among which the key ones are:

- increasing economic integration;

- new information and communication technologies;

- massive cross-border movement of large numbers of people;

- spread of global cultural forms;

- emergence of global environmental, economic, social and political problems, etc.

All this requires thoughtful consideration in determining the strategy, as well as responsiveness of teachers. Decades of development of science and research of the educational globalization led to the formation of many approaches to determining how "truly global" education should look like. However, there is still no unity on this issue.

At the same time, regardless of what events, trends and challenges the world will face in the next decade, one thing is certain: the world today is subject to rapid, 
far-reaching changes on a global scale. Pedagogical community tends to treat it as a problem and does not see that, at the same time, the era of dynamic changes provides a wide range of possibilities. The key difficulty that stands in the way of their realization in the field of education today is that the world is in a state of hyperchanges that need to be taken into consideration. Today, education more and more comes to the need to prepare the citizens of tomorrow to live in conditions of continuous acceleration of the pace of life and the unpredictable turns of world history, rather than for a single pre-determined career until retirement. At the same time, the educational community in the first place is responsible for the transfer of the aggregate wisdom of the past, fruits of the most beautiful hearts and minds that preceded us, the values of truth,justice and compassion, which should be developed to provide the public prosperity.

The effective functioning of education in the world of hyper-changes will require theoretical knowledge, practical skills and attitudes that are markedly different from those required a century or even half a century ago. Education, as before, must deliver to the younger generation a basic knowledge of mathematics, science, native and foreign language and literature, as it always has done. But apart from that, today, most education should actively encourage students' ability to think, create, communicate and solve problems on their own, as well as cultivate their innate ability to objectively assess a variety of perspectives. Armed with this range of skills and knowledge, students will be ready to face continually updated challenges and trends, independently creating their own prosperous future.

Considering economic and other problems which are faced by national education systems in the context of globalization, in the author's opinion, it is necessary to come to the positive attitude to the undergoing changes, to look for new opportunities, rather than admit the existence of difficulties. Today, in the developing knowledge economy, education will gradually become the leading industry comparable to advanced research and production of high-tech equipment. At the same time, the key problem, which inevitably will face the globalizing education, is managed by unsynchronized state and non-state education systems in national and global planes. The solution of this problem, according to the author, is to develop a comprehensive approach to the organization and management of education, where the paradigm of knowledge and skills discussed above will be combined in a rational way.

\section{References}

1. H. De Wit, Internationalization of higher education in the United States of America and Europe. 4 (Westport, CT: Greenwood, 2002).

2. C. Kerr, The internationalisation of learning and the nationalisation of the purposes of higher education: Two "laws of motion" in conflict? Eur J of Educ, 25, 5-22, (1990).
3. L. Arefiev A Russian Higher Schools on the International Market of Educational Services (Social Forecasting Center, Moscow, 2007). [In Rus]

4. T. Friedman The lexus and the olive tree (Anchor Books, New York, 1999).

5. L. Tikly Globalisation and education in the postcolonial world: Towards a conceptual framework, Comp Ed, 37(2), 156 (2001).

6. C. Tilly, Past, present, and future globalizations (Teachers College Press, New York, 2004).

7. Pennycook Global Englishes and transcultural flow (Routledge, New York, 2006).

8. M.Suárez-Orozco, C. Suárez-Orozco, Globalization, immigration, and education: Recent trends (Vatican City, 2006).

9. F.Sarah Balistreri, Tony Di Giacomo, Ivanley Noisette, Thomas Ptak, Global Education: Connections, Concepts, and Careers, 10, (College Board, 2012).

10. T. Monahan, Globalization, technological change, and public education (Routledge, New York, 2005).

11. J.Cohen, M.Malin (Eds.), International perspectives on the goals of universal basic and secondary education 68-69 (Routledge Press, New York, 2009).

12. Chris Dede, Comparing Frameworks for 21st Century Skills In 21st Century Skills, 3-19, (Solution Tree Press, Bloomington, 2010).

13. F.Reimers, Global competency» is imperative for global success, The Chr of Hi Educ, 55, iss 21, A29, (2009).

14. V.A.Myasnikov, I.A. Tagunova, N. N. Naidenova Education in the global dimension (ITIP RAE, Moscow, 2009) [In Rus]

15. B.L.Wulfson, Ec. of educ., 1, 17 (2012) [In Rus]

16. A.K.Savina, Educ. in Russia, 31, (2013) [In Rus] 